\title{
Intervenção Comunitária com Crianças / Community Intervention with Children
}

https://doi.org/10.21814/uminho.ed.36.38

Gabriela de Pina Trevisan

ProChild CoLAB, Guimarães, Portugal 



\section{Intervenção Comunitária com Crianças}

Os pressupostos teórico-metodológicos da intervenção comunitária podem ser diversos, dependendo dos contextos e tradições teóricas em que se insiram. De modo genérico, a intervenção comunitária procura fazer um trabalho sistemático, organizado e estruturado em torno de "respostas" a diferentes grupos, com necessidades distintas, e sujeitas a fatores de vulnerabilidade diversos (ex.: desemprego, emprego precário, pobreza, exclusão social, abandono escolar, baixas qualificações, etc.). Assim, "considerar a intervenção social como um ato exclusivamente técnico é esquecer a dimensão ideológica e política que subjaz em todo o comportamento social" (Quintas, Froufe, Castaño \& Angels, 1994, citados por Cortesão \& Trevisan, 2006, p. 62). 0 desenvolvimento destas intervenções obriga, por isso, a colocar os sujeitos e as suas necessidades e aspirações assumindo a sua centralidade, reconhecendo a sua autonomia, liberdade e o direito à participação nos seus próprios projetos de vida. Baseada em métodos e processos que incentivam o empoderamento dos seus grupos, e onde a participação e cidadania se constituem como linhas orientadoras da mesma, a intervenção comunitária entende as comunidades enquanto espaços socializadores, de construção de identidades locais e coletivas, de redes sociais e de suporte a indivíduos e grupos sociais, que partilham espaços, valores, formas de convivência. As novas perspetivas sobre desenvolvimento, reconhecendo o papel da globalização, assumem a necessidade de valorização do local e comunitário como forma de combate às situações de marginalização, exclusão social e desigualdade. Deste modo, as comunidades deverão poder organizar-se no sentido de se constituírem como espaços de exercício de cidadania, de ação cívica e política, numa palavra, como espaços de participação. É neste sentido que a intervenção comunitária e a ação socioeducativa em comunidades ganha relevo, observando as suas potencialidades e fragilidades, mobilizando os recursos necessários e possíveis e partindo das necessidades e vontades das suas populações, envolvendo-as em projetos que para elas se assumam como significativos (Trevisan, 2008). Este tipo de intervenção é, por isso mesmo, uma de construção de cidadania dos seus grupos, onde tradicionalmente os níveis de participação política, pública e cívica são baixos. As crianças, enquanto grupo social e geracional específico, são membros constituintes dessas comunidades e, 

CHILDREN

por isso, frequentemente, objeto e sujeito de intervenções específicas. Para diferentes autores, uma perspetiva da criança como produtora de cultura próprias - culturas infantis - acompanha o processo do seu reconhecimento como ator social com voz e direitos específicos. É também neste sentido que qualquer processo de intervenção comunitária deverá ter como peça central os seus atores - e aqui, em particular, as crianças, - os que nela vivem quotidianamente, entendendo-os como parceiros nesses processos e não apenas como meros recetores de uma mudança desenhada no seu exterior desprezando, muitas vezes, a partilha de poder nesses processos de decisão. Os projetos de intervenção comunitária que envolvem crianças centram-se, frequentemente, na mobilização de estratégias de educação não formal, inseridas em contextos menos favorecidos e oferecendo um conjunto de atividades que pretendem colmatar problemas associadas à escola, a questões comportamentais, à prevenção de comportamentos nocivos para as crianças, etc. No entanto, cada vez mais tendem a mobilizar a sua participação e envolvimento, e a desenvolver ações centradas nos seus direitos e a colocá-las no centro da intervenção, mobilizando as suas formas específicas de ver e interpretar o mundo. Esta tendência alinha-se com a ideia da criança cidadã e da sua participação como processo de tomada de decisão partilhadas com adultos. Como afirma Percy-Smith (2004), a participação das crianças é mais do que envolvimento na tomada de decisões, sendo necessário criar estruturas para que ela aconteça, mas, também a possibilidade de "as pessoas expressarem seus valores por meio do uso do espaço no fluxo da vida quotidiana dentro das comunidades" (Percy-Smith \& Malone, 2001). Invariavelmente existe uma diversidade de culturas dentro de uma comunidade (com o que quero dizer variações de valores, crenças, normas sociais, estilos de vida, etc.), incluindo a das crianças. De modo a tornar-se transformadora, a intervenção comunitária com crianças terá de mobilizar estratégias e metodologias de investigação participativas que as coloquem no centro das suas ações desenhadas com elas e para elas, e que as motivem a expressar as suas necessidades e aspirações.

\section{Community Intervention with Children}

The theoretical and methodological frameworks of community intervention can be diverse, depending on the theoretical contexts and traditions in which they are inserted. In general, community intervention seeks to perform systematic, organized and structured work around "responses" to different groups, with different needs, and subjected to different vulnerability factors (eg, unemployment, precarious employment, poverty, social 
exclusion, school dropout, low qualifications, etc.). Thus, "considering social intervention as an exclusively technical act is to forget the ideological and political dimension that underlies all social behavior" (Quintas, Froufe, Castaño, \& Angels, 1994, cited by Cortesão \& Trevisan, 2006, p. 62). The development of these interventions requires, therefore, an approach to the subjects and their needs and aspirations that assumes their centrality, and recognizes their autonomy, freedom and the right to participate in their own life projects. Based on methods and processes that encourage the empowerment of its groups, and where participation and citizenship are its guiding principles, community intervention understands communities as socializing spaces, for building location and collective identities, social networks and support for individuals and social groups, who share spaces, values, forms of coexistence. The new perspectives on development, recognizing the role of globalization, assume the need to value the local and community as a way of combating situations of marginalization, social exclusion and inequality. In this sense, communities should be able to organize themselves in order to become spaces for exercising citizenship, civic and political action, in short, as spaces for participation. It is in this sense that community intervention and socio-educational action in communities gains prominence, observing their strengths and weaknesses, mobilizing the necessary and possible resources and starting from the needs and wants of their populations, involving them in projects that they assume themselves as significant (Trevisan, 2008). This type of intervention is, therefore, one of perceive building citizenship among its groups, where traditionally the levels of political, public and civic participation are low. Children, as a specific social and generational group, are constituent members of these communities and, therefore, are often the object and subject of specific interventions. For different authors, a child's perspective as a producer of their own culture - children's cultures - accompanies the process of their recognition as a social actor with a specific voice and rights. It is also in this sense that any process of community intervention should have as its centerpiece its actors (and here, in particular, the children) those who live within the community on a daily basis, understanding them as partners in these processes and not just as mere recipients of a change designed on the outside, is often neglected where sharing of power in these decision-making processes. Community intervention projects involving children often focus on the mobilization of non-formal education strategies, inserted in less favored contexts and offering a set of activities that aim to address problems associated with school, behavioural issues, and the prevention of harmful behaviours to children, etc. However, they 
increasingly tend to mobilize their participation and involvement, to develop actions focused on their rights and to place them at the centre of the intervention, mobilizing their specific ways of seeing and interpreting the world. This trend is in line with the idea of children's citizenship and their participation in decision-making processes shared with adults. As Percy-Smith (2004) argues, children's participation is more than involvement in decision-making, it is necessary to create structures for it to happen, but also the possibility of "people expressing their values through the use of space in the flow of daily life within communities" (Percy-Smith \& Malone, 2001). There is invariably a diversity of cultures within a community (in values, beliefs, social norms, lifestyles, etc.), including that of children. In order to become transformative, community intervention with children will have to mobilize participatory research strategies and methodologies that place them at the centre of their actions designed with them and for them, and that motivate them to express their needs and aspirations.

\section{Referências / References}

Cortesão, I. \& Trevisan, G. (2006). O trabalho sócio-educativo em contextos não formais análise de uma realidade. Cadernos de Estudo, 5, 61-74.

Percy-Smith, B. (2004). Changing Cultures, Changing Spaces: Developing Neighbourhood Spaces for Children Using Community Social Learning. Paper presented at the Open Space People Space an international conference on inclusive environments, http://www.openspace. eca.ac.uk/conference/proceedings/PDF/Percy.pdf.

Sarmento, M., Trevisan, G., Grangeia, H., Sousa, M., Guedes de Oliveira, I., Pinto, A., Sampaio, A., Figueiredo, B., Bento, G., Carvalho, M., Freire, T., Matos, M. \& Soares, I. (2020). Intervenção local com crianças e famílias face à pandemia COVID-19: ProChild CoLAB em Guimarães (pp. 66-95). In A Universidade do Minho em Tempos de Pandemia. Tomo II. Reações. Braga: Editora UMinho. https://doi.org/10.21814/uminho.ed.24.4

Trevisan, G. (2008). Intervenção comunitária e inclusão social: o educador e os actores. Cadernos de Estudo, 14, 1-5. 